Article

\title{
Green and Sustainable Entrepreneurial Intentions: A Mediation-Moderation Perspective
}

\author{
Iftikhar Hussain ${ }^{1, *(\mathbb{D})}$, Mehrab Nazir ${ }^{2} \mathbb{D}$, Saadia Bano Hashmi ${ }^{3}$, Assunta Di Vaio ${ }^{4} \mathbb{D}$, Imrab Shaheen ${ }^{5}$, \\ Muhammad Arfaq Waseem ${ }^{6}$ and Adeel Arshad ${ }^{7}$
}

1 Faculty of Computing \& Engineering, University of Kotli Azad Jammu \& Kashmir, Kashmir 11100, Pakistan

2 School of Economics and Management, Jiangsu University of Science and Technology, Zhenjiang 212003, China; mehrabnazir9@gmail.com

3 Department of Governance and Public Policy, National University of Modern Languages, Islamabad 44100, Pakistan; sadia.hashmi@numl.edu.pk

4 Department of Law, University of Naples Parthenope, 80132 Naples, Italy; susy.divaio@uniparthenope.it

5 Department of Public Administration, University of Kotli Azad Jammu \& Kashmir, Kashmir 11100, Pakistan; imrabs@yahoo.com

6 Department of Commerce, University of Kotli Azad Jammu \& Kashmir, Kashmir 11100, Pakistan; arfaqtabassum@yahoo.com

7 Department of Business Administration, University of Kotli Azad Jammu \& Kashmir, Kashmir 11100, Pakistan; adeelarshade@gmail.com

* Correspondence: iftikhar_raja@live.com

check for updates

Citation: Hussain, I.; Nazir, M.; Hashmi, S.B.; Di Vaio, A.; Shaheen, I.; Waseem, M.A.; Arshad, A. Green and Sustainable Entrepreneurial Intentions: A Mediation-Moderation Perspective. Sustainability 2021, 13, 8627. https://doi.org/10.3390/ su13158627

Academic Editor: Antonio M López Hernandez

Received: 25 May 2021

Accepted: 16 July 2021

Published: 2 August 2021

Publisher's Note: MDPI stays neutral with regard to jurisdictional claims in published maps and institutional affiliations.

Copyright: (c) 2021 by the authors. Licensee MDPI, Basel, Switzerland. This article is an open access article distributed under the terms and conditions of the Creative Commons Attribution (CC BY) license (https:// creativecommons.org/licenses/by/ $4.0 /)$.
Abstract: This research was aimed to investigate the connection between the social networking sites and green entrepreneurship intentions through a mediated-moderated model. The study was based on the Shepero's model of entrepreneurship intentions and Ajzen's theory of planned behavior. The study design reflects that social networking sites and green entrepreneurship intentions are mediated by risk propensity and self-efficacy, while self-efficacy and green entrepreneurship intentions' relationship is further moderated by subjective norms. A well-structured and selfadministered questionnaire was used to collect data from 500 respondents. The data were analyzed, and hypotheses were tested using PLS-SEM. The study findings confirmed that there exists a positive and significant link between social networking sites and green entrepreneurship intentions through the indirect effect of risk propensity and self-efficacy. However, the findings regarding moderating effect indicated that subjective norms have no significant impact between the self-efficacy and green entrepreneurship intentions. The study findings have significant academic and practical implications for government representatives, policymakers, and entrepreneurial educational institutes that can use these findings.

Keywords: social networking sites; risk propensity; self-efficacy; subjective norms; green and sustainable entrepreneurial intention

\section{Introduction}

The fast increase in human population has resulted in a dramatic change in human buying patterns, and this has indirectly and directly affected the human well-being. These developments have resulted several damages to global environment such as intensification in environmental emissions, climate change, and decline in flora and fauna. Over time, such changes and uncertainties in global climate has impacted the service quality at both human and systematic levels. Such changes in global climate and market have brought many changes in consumers' priorities regarding environmental changes, perceptions, and investments [1]. Entrepreneurship concept was introduced in the 17th century. This concept has different meanings and uses in different concepts and dimensions. Conventionally, this concept was taken as a business started to gain profit. Some entrepreneurs are taking the concept of entrepreneurship as a process of introducing good quality new products and 
services to customers for fulfilling their needs and requirements. However, the concept has transformed to green entrepreneurship and has been associated deeply with the green economy. The businesses are also changing with the changing global environment and are concentrating more towards sustainability and ecological issues [2]. According to a study, entrepreneurs are taking this situation as an opportunity and are making investments as well as taking risks willingly [3]. The green entrepreneurship and environmental concerns have remained the focus of researchers in recent decades. On the other hand, green entrepreneurship has also been identified as an answer to economic, as well as social, problems expanding due to ecological changes $[4,5]$.

Another study augmented that green entrepreneurship causes many advantages, e.g., helps in improving and maintaining ecological system, reduces deforestation, and provides a better quality environment [6]. The concept of green entrepreneurship is gaining rapid attention among university graduates, and their intentions towards green entrepreneurship is improving rapidly. The effect of both individual factors, as well as contextual factors, is very substantial in sustaining green entrepreneurship. However, contextual factors such as the support provided by the governmental universities and vocational institutions through green entrepreneurship initiatives, as well as maintaining law and ordinance situations, has a relatively greater impact [7]. There are other important benefits associated with green entrepreneurship such as better job opportunities, as well as some social and economic benefits, for the states where this concept has been realized [7,8]. These advantages and some others have gained the attention of governments and their policy makers over the time. They are taking green entrepreneurship as a potential source for rapid economic and social development. They are thinking that this process involves some potential risks. However, it has the ability to transform low productive units into highly productive operations [9].

The concept of green entrepreneurship has remained the focal point for many researchers as well as policy makers in recent decades. The reason behind this potential increase in concentration upon green entrepreneurship is the ever-increasing need of entrepreneurs and new businesses. The entrepreneurs are a vital source of economic development, they generate economic activities and create income opportunities for themselves, as well as for the state, by creating and generating viable business ideas and translating these ideas into profitable undertakings. The entrepreneurs not only have led many technological and scientific innovations but also have contributed significantly to providing many job opportunities and maintaining businesses competitiveness. The drastic digitalization has resulted in many changes regarding green entrepreneurship, the social media has been recognized as the most significant source of exchanging information. The social networking sites has become a key source of leveraging current and viable information. Especially, social networking sites and channels are more influential and useful in providing quick and reliable information during the crisis and disasters [10]. The establishment of social media channels and social networking sites as an effect media has also resulted in a great focus on environmental issues, as well as assurance of a better-quality environment through creating awareness among people. The campaigns for a better and green environment on social media and social networking sites has also promoted the green entrepreneurship concept and intentions among university graduates and other young minds [11].

Pakistan is one of those countries which is trying hard to improve the economic, as well as social, conditions of their people. However, even until today the state has not been successful in realizing this goal. Pakistan is facing many social and economic challenges; unemployment is one of them. Many university graduates are unable to find a suitable job. The government and its institutions can do a little, and the concept of entrepreneurship can help a lot in combating such situations. If properly addressed and concentrated, the entrepreneurship, especially the green entrepreneurship, can help Pakistan in combating economic issues such as unemployment, as well as social and environmental issues. The use of social media and social networking sites can become effective to create entrepreneurial intentions among university graduates as well as other young minds. The extensive use 
of social networking sites and social media channels also helps in developing self-efficacy and reducing the risk perceptions among entrepreneurs. However, unfortunately, these concepts have not been concentrated in developing economies, especially in Pakistan. Therefore, this study was aimed to fill this gap and investigate the concept of green entrepreneurship and its significance for economic and social development of Pakistan through social networking sites, self-efficacy, risk propensity, and subjective norms. The current study was based upon Ajzen theory of planned behavior and Shapero's model.

The remainder of this article is organized as follows. Section 2 introduces the theoretical background, while Section 3 describes the methodology using to develop the research. Section 4 provides the data analysis, and Section 5 contains the discussion and provides conclusions future implications.

\section{Literature Analysis}

Some of the most fundamental determinants of entrepreneurial intention are identified by Shapero and Sokol [12]. Two variables from his model were selected to discuss the relationship between them. The relationship between self-efficacy, green entrepreneurial intention, and risk propensity is empirically supported Pop, Săplăcan [13]. Moreover, Ajzen's theory of planned behavior is compared with Shapero and Sokol [12] model by numerous researchers [14]. The relationship between self-efficacy, green entrepreneurial intentions, and risk propensity is verified by them. One intentional decision of opening a new business is influenced by one's behavior intention. Ajzen's theory of planned behavior is one of the most fundamental theories for forecasting behavioral intention. Behavioral intention is predicted by this theory, which indicates the interaction between people and the community [15].

\subsection{The Role of Use of Social Networking Sites in Emerging Pandemics}

Social Networking sites act as a channel of different tools, which helps to gather and share information among groups for providing risk related native source of traditional media. During epidemic crises, social networking sites have developed an indispensable measure of risk communication due to the advanced foundation of Web 2.0. Social networking sites enable users to distribute real-time information about the latest facts during decisive situations and prohibit neutrally to act as sources of exchange information [16]. Government and private organizations use these social networking sites as proactive emergency management by which updated information pertaining to current issues is disseminated during an infectious disease outbreak.

Online social network has a significant role in the entrepreneurial life. Hence, social networking sites play a vital role in bringing innovation by the flow of knowledge without constraints, thereby shaping entrepreneurial ecosystem. McQuaid [17] investigated that entrepreneurs' need to invest more time and financial capital in the early stage of business development. Therefore, the use of social networking sites overcome risk at this stage of business development. Entrepreneurs can immediately access to productive resources and the consumer by establishing an appropriate collaboration. Moreover, Ajzen [18] argued that social networks have different impact on individual's behavior in reasoning, thinking, acting, and talking in accordance with the literature of psychology and sociology. Recently, social networking exerted positive influence on the easy flow of information between people in the intellectual surroundings. Recent studies have further elaborated that social media has a significant impact on student's academic performance [16].

Subjective literature studies had introduced the concept of green entrepreneurship in the business field. In this regard, Ajze's Theory of planned Behavior is the most appropriate theory for forecasting green entrepreneurship. It is an extension of theory of reasoned action [19] in which intention is defined as an individual's willingness to involve in entrepreneurial behavior or one's commitment towards generating a new venture. Green entrepreneurship is a transformation of two ideas, entrepreneurship and environment introduced by the researcher, such as $[20,21]$ at the start of 1990s. With the passage of 
time, many researchers recognized that there is no consent on its meaning or item. Gast, Gundolf [22] reviewed literature efficiently and validated various definitions of green entrepreneurship. This concept gives rise to the notions of sustainable entrepreneurship, ecologically sustainable entrepreneurship, and eco-entrepreneurship [17]. For example, the idea of green entrepreneurship addresses environmental problems by developing new and innovative products [20]. It is considered an act of entrepreneurship driven not only by revenue but also by environmental concerns [23]. Research of Schaper [24] revealed that the environmental concerns of green entrepreneurship have broadened its scope.

Green Entrepreneurship is considered as an ingenious, marketplace, personalityoriented type of value formation, which leads to new start-ups relying on associated with natural resources by adopting environmental management practices or cleaner production processes [22]. However, intentions are normally recognized as the prime paramount indicator of planned behavior $[25,26]$. Researchers focus on setting up a business venture stimulated using social networking sites in accordance with the basic concept of entrepreneurial intention [27]. The focus of entrepreneurship research has been towards the entrepreneur intention as entrepreneurship is usually taken as intended behavior [28] and entrepreneurial behaviors are the outcome of intention $[17,29,30]$. Previous literature provides clues to understand entrepreneurial phenomenon by using intention-based models [28]. These website resources are used by many young and energetic entrepreneurs to run their businesses and introduce their products in new markets due to the extremely recognized power of social networking sites and applications. Thus, these technologies are now used by businesses to expand their operations in many ways such as online marketing techniques to increase sales and brand identification. Recent research studies have further revealed that student's academic performance towards green entrepreneur intention is mainly affected by online social (networking) media [31].

Hypothesis 1 (H1). The use of social networking sites is positively and significantly related to green and sustainable entrepreneurial intentions among students.

\subsection{The Role of Use of Social Networking Sites on Self-Efficacy towards Green and Sustainable Entrepreneurship}

Entrepreneurial intention is predicted by entrepreneurial self-efficacy $[29,32]$. There is a difference between self-confidence and locus of exploitation [30]. However, new commercial enterprises are also affected by locus of control [29]. Self-efficacy is an individuals' belief in their abilities to solve complex problems in different situations [33]. Green entrepreneurship's intention is the inclination of individual to start a new ecological business having a great influence of personal capacity perception and self-efficacy [34].

According to [35], social networking sites have a great influence on individual's understating of personal capability and self-efficacy. Self-efficacy is viewed as a cognitive measure of individual stuff with concern on new venture development. Bhaskar and Garimella [36] revealed that a high degree of entrepreneurship is essential for launching a new business, which ultimately results in efficiently running and managing a company. Previous research studies argued that entrepreneurial intentions are significantly influenced by social networks especially among young individuals [37]. Social networking sites play a vital role in improving learning, growing entrepreneurial skills, and building relations with other competitors. Access to technology, information, and technology is essential for continuous growth and acceptability of entrepreneurs. Measurement and type of social community that they call on to harmonize knowledge, may vary among entrepreneurs [38]. Probability of success can be increased by social networks at various stages of business growth in different ways. Social networking sites are a key to success in a series of approaches at an exclusive business improvement stage. Low self-efficacy rate results in incompetency of individuals to combat with uncertain situations. Literature also suggested some measures to grow and lower the degree of an individual's self-belief by using social networking sites for overcoming their social and financial problems. Individuals' needs and demands can easily be customized by using social networking sites [39]. Thus, social 
networking sites play a vital role in fulfilling individuals' needs to articulate self-efficacy towards green entrepreneurship intention.

Hypothesis 2 (H2). The use of social networking sites is positively and significantly related to self-efficacy among students.

Hypothesis 3 (H3). The relationship between use of social networking sites and green and sustainable entrepreneurial intensions among the students is mediated by self-efficacy.

\subsection{Risk Propensity}

Many research studies have anticipated a direct link between risk propensity and entrepreneurial intentions. Therefore, it is assumed that self-efficacy and risk propensity mediates towards green entrepreneurship in this research study. In other words, green entrepreneurial venture is chosen by those individuals who exhibit a higher risk tendency in the way of task performance. In the sense of SNS, users' social interactions and usage patterns were affected by privacy risk. Public risk perception is reduced by a substantial source of social media [40]. Social networking sites play a vital role in data mining for businesses by tracking all communication between users. The current study has revealed that business activities are positively influenced by knowledge sharing, such as the efficiency of decision making to start a new business and the strength of the experience among critical stakeholders [41-43]. Likewise, social media platform users' information sharing activities are also very important for individuals as well as organizations to gather valuable data for devising strategies to improve their businesses. Social networking sites are used by individuals to get information, overcome risk, and leveraging to get a positive response [44]. While attempting a green entrepreneurial venture, by considering the theoretical mechanisms affecting self-efficacy, we supposed the risk propensity to have been connected to the individual's judgment of their likely physiological condition.

Gist and Mitchell [45] investigated that individual feel more comfortable in solving problems during uncertain conditions when they possess a high degree of risk propensity. Therefore, they feel more self-efficiency, greater sense of control over results, assess the prospect of obtaining noteworthy rewards and expect a less crippling doubt about entrepreneurial career. University students are encouraged to participate in green entrepreneurship by gaining related experience and specific technical innovation and abilities [46]. Additionally, Adekiya and Ibrahim [47] revealed that intention is determined by culture, behavioral role models, personality traits, and job experience [29].

Hypothesis 4 (H4). The use of social networking sites is positively and significantly correlated with risk propensity among students.

Hypothesis $\mathbf{5}$ (H5). The relationship between use of social networking sites and green and sustainable entrepreneurship intentions among students is significantly mediated by risk propensity.

\subsection{Subjective Norm as a Moderator}

Individuals' perceived expectations have toward significant others reflect subjective norms [18]. Subjective norms are defined by entrepreneurial research as an individual's perceptions of reference people such as family, friends, and significant others, who can influence the decision of becoming an entrepreneur [48]. According to this definition, subjective norms relevant to entrepreneurship can be negative or positive; however, positive subjective norms are focused on this research study. Relevant research studies have discussed the impact of subjective norms on entrepreneurial intention [49,50]. Although individual's entrepreneurial motivation is affected by reference groups, they may provide support to individuals in starting a business; thereby boost the roles of perceived behavioral control and personal attraction [51]. Thus, on the base of relevant research, this research study emphasizes that subjective norms affect both the effects of entrepreneurial selfefficacy on green entrepreneurial intention. 
Hypothesis 6 (H6). The relationship between self-efficacy and green and sustainable entrepreneurship intentions among students is significantly moderated by subjective norms.

\subsection{Conceptual Framework}

Based on literature analysis the research framework designed and used in this study was illustrated in Figure 1.

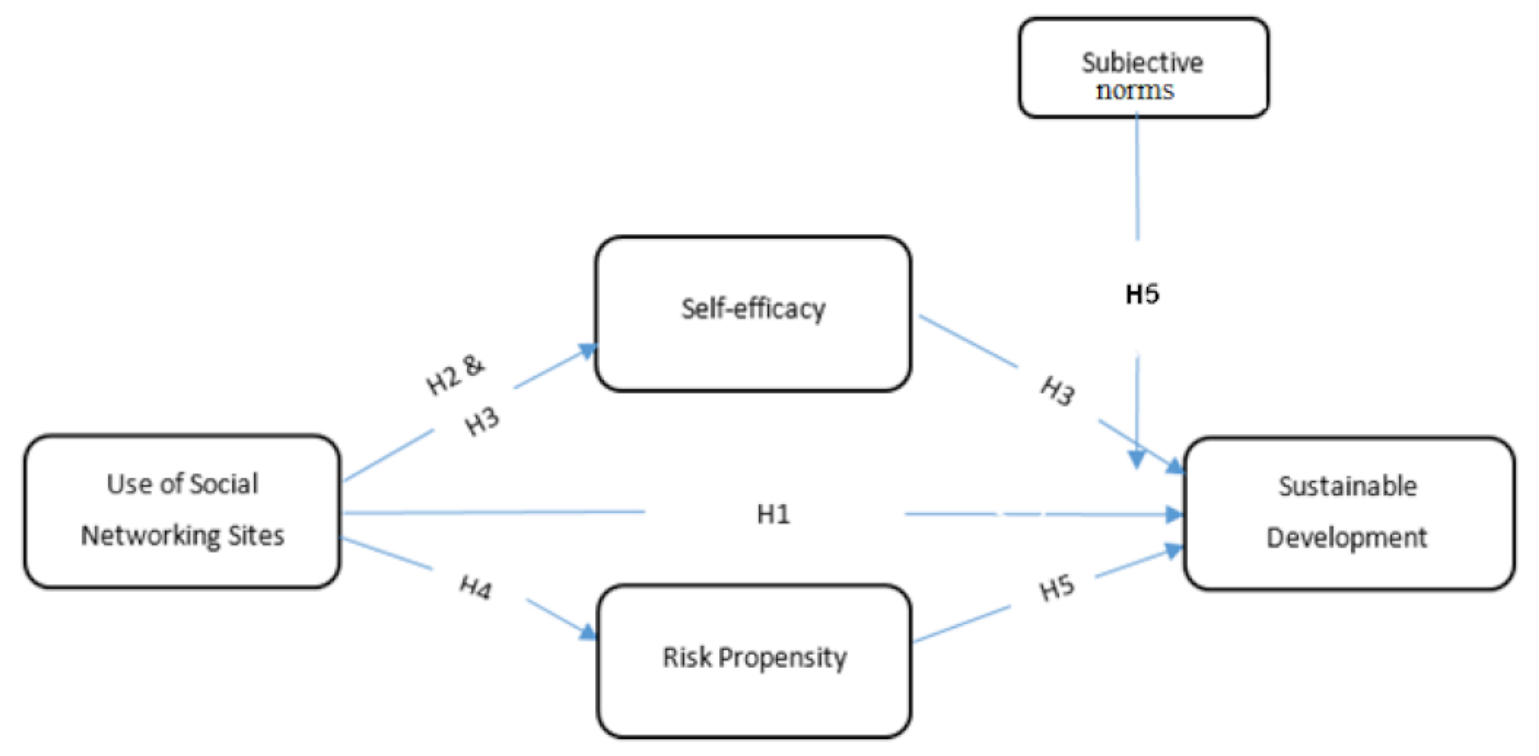

Figure 1. Research Framework.

\section{Methodology}

A structured questionnaire was utilized to gather empirical data to test the developed hypotheses. The structured questionnaire comprises three parts, "first section," which has begun with the demographic characteristics of students, the second section with general evaluative data for the use by social networking sites as an independent variable and the green entrepreneurial intention variable as a dependent variable. The third section consisted of the relation of the remaining three variables (self-efficacy, risk propensity, and subjective norm). All 300 university students from Lahore and Faisalabad attended the questionnaire. This sample size [52] allowed for at least 300 samples to be used to estimate the $\mathrm{C} \alpha$-coefficient correctly. The research participants were chosen through a convenience sample. The main benefit of the choosing convenience sampling technique is that it allows the researchers to comply in a relatively short time with the necessary information from many respondents. To compute structural equation modelling analysis, many studies have utilized and recommended a minimum number of samples of 300 .

Consequently, the investigator used a minimum number of sample sizes of 300 in this study $[52,53]$. The sample was analyzed using the software SPSS and PLS-SEM. The investigator employed the scale of Likert 5 points. Table 1 findings showed that $65.33 \%$ are males and the remaining $34.66 \%$ are females, according to the demographic patterns of the attended students. One of those interviewed was $80 \%$ of the students between 20 to 30 years of age, $15 \%$ between 30 and 40 , while the other $5 \%$ were between 40 and $50 \%$. Some $65 \%$ of them have bachelor's degrees, $25 \%$ have master's, and $10 \%$ are post-graduates. We also examined the sponsored student income, and more than 30,000 earnings per month are recorded for most students. Questions about the usage of social networking sites have been applied [54], risk propensity questionnaires have been adapted from [55], the items for subjective norm adopted from [56], while self-efficiency and green entrepreneurship intention has been adopted [57]. 
Table 1. Demographic variables.

\begin{tabular}{cccc}
\hline Variable & Category & Frequency & Percentage \\
\hline \multirow{2}{*}{ Gender } & Male & 196 & 65.33 \\
& Female & 104 & 34.66 \\
\hline \multirow{3}{*}{ Age (Years) } & $20-30$ & 240 & 80.0 \\
& $31-40$ & 45 & 15.0 \\
& $41-50$ & 15 & 5.0 \\
\hline \multirow{3}{*}{ Qualification } & Bachelors & 195 & 65.0 \\
& Masters & 75 & 25.0 \\
& Postgraduates & 30 & 10 \\
\hline \multirow{3}{*}{ Income } & $1-10,000$ & 36 & 12.0 \\
& $10,000-20,000$ & 15 & 5.0 \\
& $20,000-30,000$ & 75 & 25.0 \\
& $30,000-$ above & 174 & 58.0 \\
\hline
\end{tabular}

\section{Results and Discussions}

\subsection{Data Analysis}

The researcher utilized PLCS statistical software in the early phase to identify the missing values, mistakes, and common method biases in the data obtained. Data were gathered from separate sources; thus, it was compulsory to check the common method variance [58]. A single factor test results showed that the first factor is 22.52 percent below the variance threshold [58], which is less than 50 percent. Thus, there is no problem in this study about the typical technique bias. The researcher has evaluated discrimination in validity and convergent validity to evaluate the measurement model. According to Hair, Celsi [59], Convergent validity is established through factor loading, CR, and average variance extracted (AVE). The CR values of all items were higher than 0.953 , according to the results of Table 1, and the AVE of all structures was more than 0.800 . Therefore, every item's convergent validity has been achieved. Another reliability of the measuring model was evaluated in this research. The confidence has shown that our 20 composite reliability components are predictable, and every item's value varies from 0.916 to 0.935 , which shows a solid internal consistency indication.

Table 2 demonstrated that any number relationship describes the connection between two random variables or a binary data collection. The association was determined to be significant for $p<0.05$ and $0.01 \%$ respectively [59]. Besides, all the results of heterotraitmonotrait (HTMT) ratio as indicated in Table 3 were smaller than the recommended value of 0.724 thus supporting DV [60].

\subsection{Structural Model}

The connection between all endogenous and exogenous variables is explained in Table 4 and Figure 2. Structural equation [61] was utilized in this analysis and empirical study to evaluate the impact of social networking sites on the green entrepreneurial intention with mediated and moderated variables of risk propensity, self-efficacy, and subjective norm. In this research, the hypothesis was statistically estimated using statistical software (SPSS 20 and PLS-SEM). Standard beta, R2 standard, and $p$-value and $\mathrm{t}$-value were evaluated using bootstrapping processes to evaluate SEM with a resample from 2000. 
Table 2. FLs, AVE, CR and CA of all constructs.

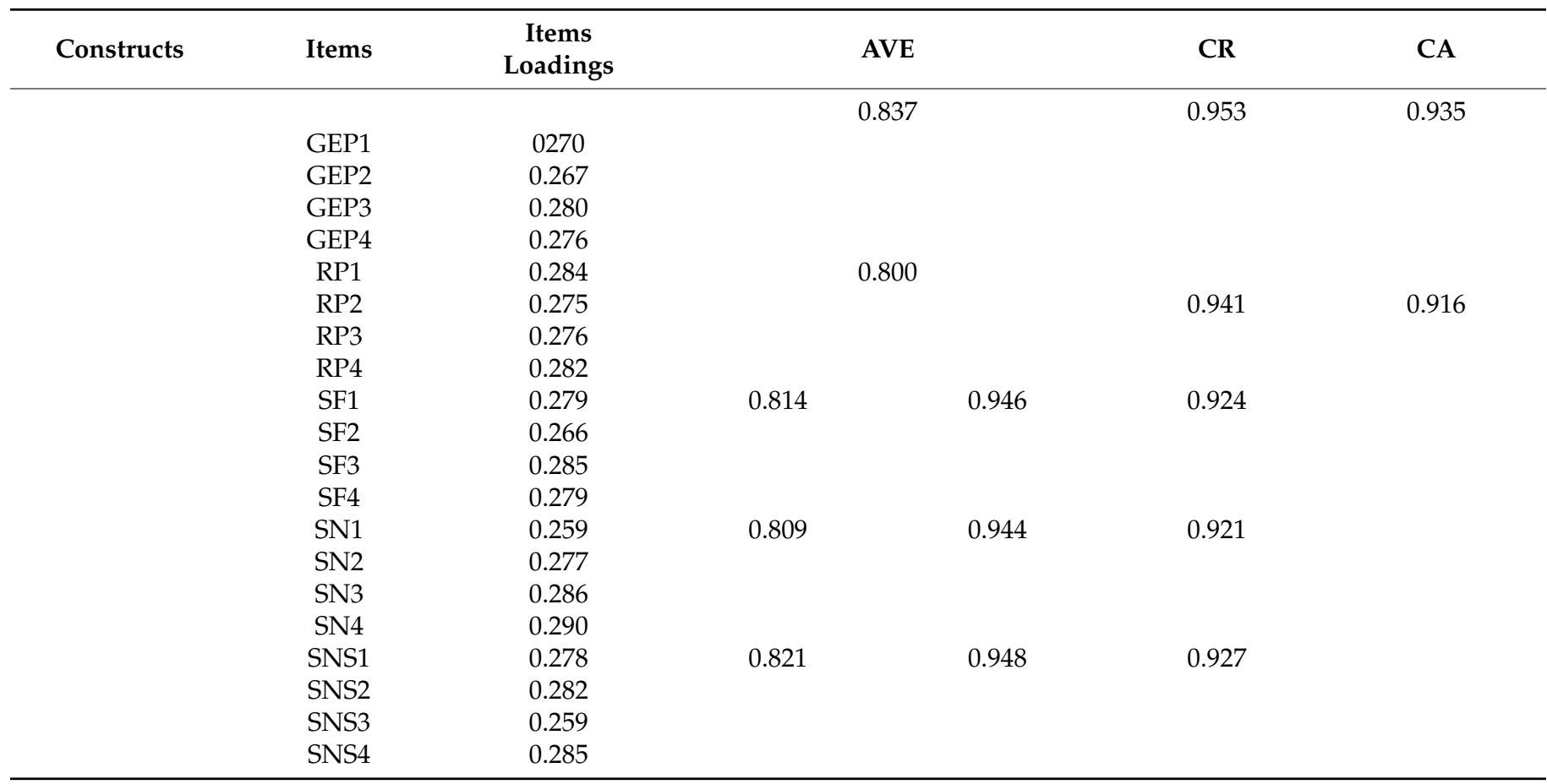

Table 3. Heterotrait-Monotrait Raito (HTMT).

\begin{tabular}{ccccc}
\hline & GEP & RP & SF & SN \\
\hline GEP & & & & \\
RP & 0.813 & & & \\
SF & 0.812 & 0.842 & & \\
SN & 0.829 & 0.887 & 0.777 & 0.724 \\
SNS & 0.786 & 0.739 & 0.865 & \\
\hline
\end{tabular}

Table 4. Direct Effects.

\begin{tabular}{ccccccccc}
\hline Hypothesis & Relationship & Beta & $\begin{array}{c}\text { T } \\
\text { Values }\end{array}$ & $\begin{array}{c}p \\
\text { Values }\end{array}$ & BCILL & BCIUL & $\mathbf{f}^{2}$ & VIF \\
\hline & RP -> GEP & 0.160 & 2.219 & 0.027 & 0.014 & 0.300 & 0.024 & 3.846 \\
SF - GEP & 0.208 & 2.700 & 0.007 & 0.053 & 0.358 & 0.034 & 3.893 \\
SF*SN - - GEP & 0.016 & 0.492 & 0.623 & -0.040 & 0.092 & & 0.117 \\
SN - > GEP & 0.341 & 4.104 & 0.000 & 0.169 & 0.492 & 2.258 \\
SNS -> GEP & 0.237 & 2.747 & 0.006 & 0.068 & 0.404 & 0.065 & 2.955 \\
SNS - RP & 0.682 & 18.014 & 0.000 & 0.599 & 0.749 & 0.869 & 1.000 \\
SNS - SF & 0.802 & 32.62 & 0.000 & 0.748 & 0.844 & 1.800 & 1.000 \\
\hline
\end{tabular}

There were six hypotheses addressed in this research. Based on statistical Table 4, all hypotheses are positive and significant, while two variables are not significant. For the $\mathrm{H} 1$ of $\beta=0.0 .346$ and $p<0.01$, for the $\mathrm{H} 2$ of $\beta=0.0 .802$ and $p<0.01$, for the $\mathrm{H} 3$ of $\beta<0.0 .682$ and $p<0.01$, for the H4 of $\beta 0.208$ and the H5 of $\beta<0.160$, for the H6 of $\beta<0.016$ and $<0.01$.

According to the required results of hypothesizes, all hypothesizes have supported, but H6 has not supported. So subjective norm does not support the relationship between self-efficacy and green entrepreneurship intention. According to Table 5, there exists a mediation between the variables, but according to all statistical results, there exists a partial mediation between the variables. 


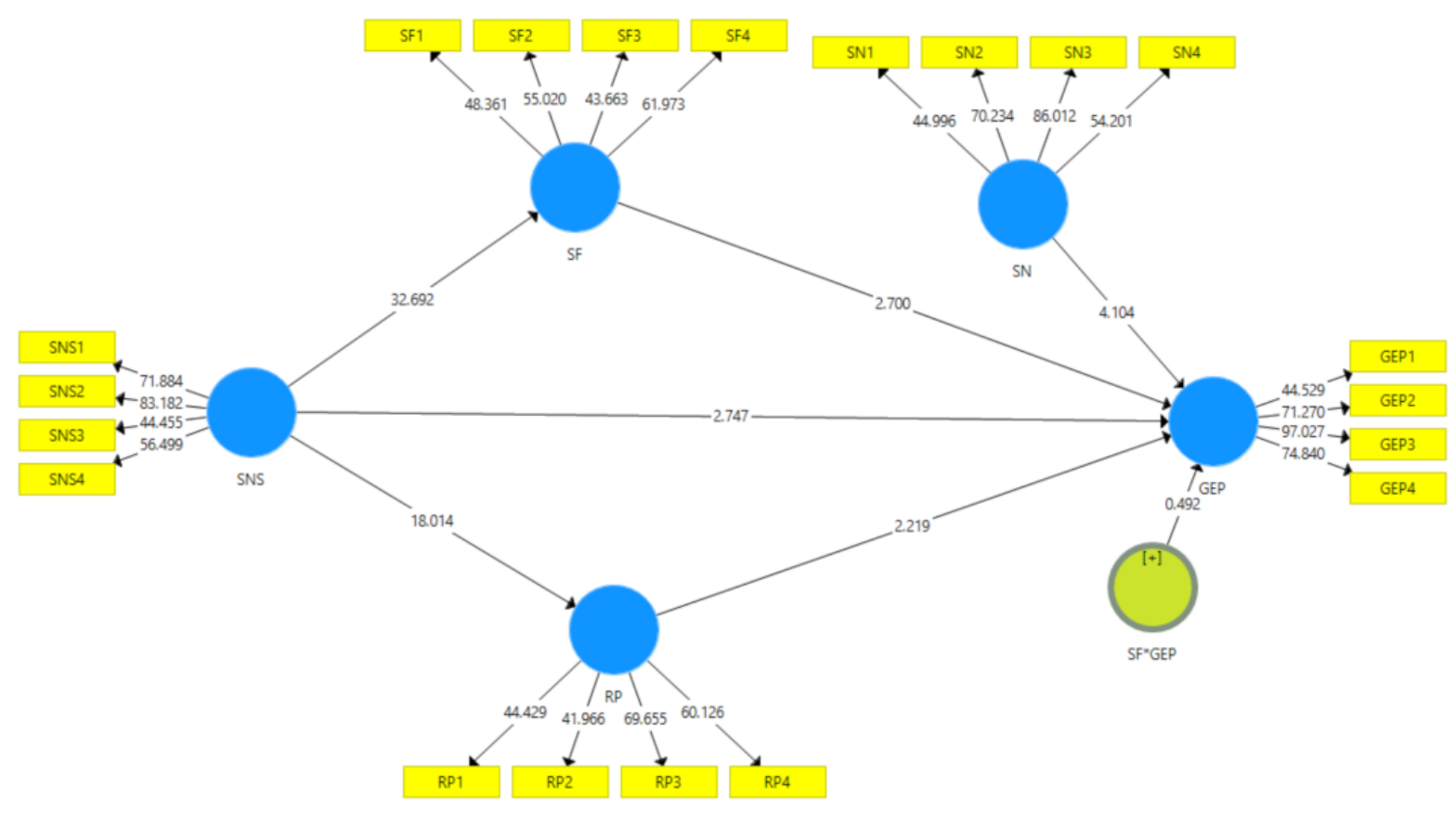

Figure 2. SEM Analysis.

Table 5. Mediation Effects.

\begin{tabular}{lcccccc}
\hline Hypothesis & Relationships & Beta & T Values & $p$ Values & $\begin{array}{c}\text { Lower } \\
\text { Limit }\end{array}$ & $\begin{array}{c}\text { Upper } \\
\text { Limit }\end{array}$ \\
\hline & SNS -> RP -> GEP & 0.109 & 2.177 & 0.030 & 0.010 & 0.211 \\
& SNS -> SF -> GEP & 0.166 & 2.696 & 0.007 & 0.044 & 0.290 \\
\hline
\end{tabular}

\subsection{Discussions}

Due to advancement in Pakistan's green wave, our primary aim was to explore five concepts: social networking sites, green entrepreneurial intentions, risk propensity, subjective norm, and self-efficacy. Numerous studies have proved that there exists a direct relation between the social networking sites and green entrepreneurship intention [62]. So, the empirical research contributions based on statistical results are as follows. First, we examined the direct connection between the variable (social websites) and the variable (green entrepreneurship intention). According to the outcome of the $p$-value, these two variables have a significant connection that social networking sites directly improve, including the engagement of university students with the green entrepreneurial intention. Second, mediating variables (risk propensity and self-efficacy) positively impact green business intentions. In addition, many studies have not shown the significant intention between the relationship of self-efficacy and green entrepreneurship intention [63]. So, the moderating variable (subjective norm) has an insignificant effect between self-efficacy and green entrepreneurial intention. So, it means that Self-efficacy relationship is not influenced by the subjective norms. When subjective norm increases, the relationship does not stay strong between the self-efficacy and green entrepreneurship intention. So, the overall relations confirmed that social networking sites play an important role in strengthening student interactions between green entrepreneurial intentions by mediating self-efficacy and risk propensity [64]. The findings revealed the beneficial influence and admiration of university students on the green enterprises that tend to the green enterprise aim. 


\section{Conclusions, Limitations, and Implications}

\subsection{Conclusions}

The results also indicated that university students maintain great passion for squeezing the green theory if they engage in speculating about business. The combination of self-efficiency and risk propensity enhanced their attractiveness for green entrepreneurship. Because of current changes in the environment and climate, students also have influential green entrepreneurial business as more safe, joyful, enjoyable, and impactful. In addition, students at universities depend on the practical approach and context of the green entrepreneurial company. In Pakistan, government and private institutions are working comprehensively to disseminate the green wave among prospective people in business. Therefore, students believe that it will not be too hard to pursue green business. His assurance of development and his collection of experience in the green business sector comprehend the feasibility of the goal of green businesses.

\subsection{Limitations}

The consequences of this study have several limitations; for example, because of the small number of respondents, any extrapolation of the findings should be done with extreme care. The research given here is a preliminary investigation into green entrepreneurship, intending to test the most significant variables that influence it, as reflected in the model shown here. As a result, additional factors that may affect green entrepreneurship may be investigated via study. In particular, the lack of environmental consciousness among businesses, public policy, and strategic planning in the nation may also be considered. Furthermore, the importance of environmental education, or, in other words, the elements stated previously, must be emphasized. Based on the findings of the present study, it is recommended that the level of environmental awareness among entrepreneurs be raised through participation in the media, education, and universities. It is also necessary to prioritize financing Environment-Friendly projects at the national level and then establish financial funds to support research in the development of sustainable and environmentally friendly products and processes.

\subsection{Implications}

This study provides an understanding of the influential factors that affect green entrepreneurial intentions. The findings can be used by planners and policymakers to develop guidelines to enhance the green entrepreneurial intentions using social networking sites, which consequently affect the whole society. To this end, planners should raise awareness by means of SNS right use to create green entrepreneurial intentions among youth. These awareness programs should also focus on the framework used and provided in this study for better understanding of the relationships studied here and their implications to managers and entrepreneurs. Going green through SNS, which was the main purpose of this study, can help in creating great entrepreneurs, economic development, and a better community.

Author Contributions: Conceptualization, I.H. and M.N.; methodology, S.B.H.; software, M.N.; validation, I.S., M.A.W. and A.A.; formal analysis, M.N.; investigation, A.A.; resources, A.D.V.; data curation, M.N.; writing —original draft preparation, I.H.; writing-review and editing, I.H. and A.D.V.; visualization, S.B.H.; supervision, A.D.V.; project administration, I.S.; funding acquisition, A.D.V. All authors have read and agreed to the published version of the manuscript.

Funding: This research received no external funding.

Institutional Review Board Statement: The study was conducted according to the guidelines of the Declaration of Helsinki and approved by the Ethics Committee of the Jiangsu University of Science and Technology.

Informed Consent Statement: Informed consent was obtained from all subjects involved in the study.

Data Availability Statement: Data can be obtained through email at mehrabnazir9@gmail.com. 
Conflicts of Interest: The authors declare no conflict of interest.

\section{References}

1. Chen, T.B.; Chai, L. Attitude towards the environment and green products: Consumers' perspective. Manag. Sci. Eng. 2010, 4, 27-39.

2. Ebrahimi, P.; Mirbargkar, S.M. Green entrepreneurship and green innovation for SME development in market turbulence. Eurasian Bus. Rev. 2017, 7, 203-228. [CrossRef]

3. Himel, T.H.; Muniandy, S.; Rahman, A. The relationship between self-efficacy, feasibility, and awareness towards green entrepreneurial intention. Sci. Int. 2016, 28, 2095-2103.

4. Demirel, P.; Li, Q.C.; Rentocchini, F.; Tamvada, J.P. Born to be green: New insights into the economics and management of green entrepreneurship. Small Bus. Econ. 2019, 52, 759-771. [CrossRef]

5. Hall, J.K.; Daneke, G.A.; Lenox, M.J. Sustainable development and entrepreneurship: Past contributions and future directions. J. Bus. Ventur. 2010, 25, 439-448. [CrossRef]

6. Shepherd, D.A.; Patzelt, H. The New Field of Sustainable Entrepreneurship: Studying Entrepreneurial Action Linking “What Is to Be Sustained" With "What Is to Be Developed. " Psychol. Approach Entrep. 2014, 35, 45-71. [CrossRef]

7. Bogatyreva, K.; Edelman, L.F.; Manolova, T.S.; Osiyevskyy, O.; Shirokova, G. When do entrepreneurial intentions lead to actions? The role of national culture. J. Bus. Res. 2019, 96, 309-321. [CrossRef]

8. Nuringsih, K.; Puspitowati, I. Determinants of Eco Entrepreneurial Intention Among Students: Study in the Entrepreneurial Education Practices. Adv. Sci. Lett. 2017, 23, 7281-7284. [CrossRef]

9. Fatoki, O.O. Graduate Entrepreneurial Intention in South Africa: Motivations and Obstacles. Int. J. Bus. Manag. 2010, 5, 87. [CrossRef]

10. Schultz, F.; Utz, S.; Göritz, A. Is the medium the message? Perceptions of and reactions to crisis communication via twitter, blogs and traditional media. Public Relat. Rev. 2011, 37, 20-27. [CrossRef]

11. Soomro, R.B.; Mirani, I.A.; Ali, M.S.; Marvi, S. Exploring the green purchasing behavior of young generation in Pakistan: Opportunities for green entrepreneurship. Asia Pac. J. Innov. Entrep. 2020, 14, 289-302. [CrossRef]

12. Shapero, A.; Sokol, L. The Social Dimensions of Entrepreneurship; University of Illinois at Urbana-Champaign's Academy for Entrepreneurial Leadership Historical Research Reference in Entrepreneurship: Champaign, IL, USA, 1982.

13. Pop, R.-A.; Săplăcan, Z.; Alt, M.-A. Social Media Goes Green-The Impact of Social Media on Green Cosmetics Purchase Motivation and Intention. Information 2020, 11, 447. [CrossRef]

14. Krueger, N.F., Jr.; Reilly, M.D.; Carsrud, A. Competing models of entrepreneurial intentions. J. Bus. Ventur. 2000, 15, 411-432. [CrossRef]

15. Singh, S.K.; Del Giudice, M.; Tarba, S.Y.; De Bernardi, P. Top management team shared leadership, market-oriented culture, innovation capability, and firm performance. IEEE Trans. Eng. Manag. 2019, 1-11. [CrossRef]

16. Ding, H.; Zhang, J. Social media and participatory risk communication during the H1N1 flu epidemic: A comparative study of the United States and China. China Media Res. 2010, 6, 80-91.

17. McQuaid, R.W. The Entrepreneur in Economic Theory; Edward Elgar Publishing: Cheltenham, UK, 2013.

18. Ajzen, I. The theory of planned behavior. Organ. Behav. Hum. Decis. Process. 1991, 50, 179-211. [CrossRef]

19. Azmitia, M.; Montgomery, R. Friendship, transactive dialogues, and the development of scientific reasoning. Soc. Dev. 1993, 2, 202-221. [CrossRef]

20. Adebiyi, S.O.; Oyatoye, E.O.; Mojekwu, J.N. Predicting Customer Churn and Retention Rates in Nigeria's Mobile Telecommunication Industry Using Markov Chain Modelling. Acta Univ. Sapientiae Econ. Bus. 2015, 3, 67-80. [CrossRef]

21. Burzyńska, D.; Jabłońska, M.; Dziuba, R. Opportunities and Conditions for the Development of Green Entrepreneurship in the Polish Textile Sector. Fibres Text. East. Eur. 2018, 26, 13-19. [CrossRef]

22. Gast, J.; Gundolf, K.; Cesinger, B. Doing business in a green way: A systematic review of the ecological sustainability entrepreneurship literature and future research directions. J. Clean. Prod. 2017, 147, 44-56. [CrossRef]

23. Blue, J. Ecopreneuring: Managing For Results; Scott Foresman: London, UK, 1990.

24. Schaper, M. Introduction: The Essence of Ecopreneurship. Greener Manag. Int. 2002, 2002, 26-30. [CrossRef]

25. Jolink, A.; Niesten, E. Sustainable Development and Business Models of Entrepreneurs in the Organic Food Industry. Bus. Strategy Environ. 2015, 24, 386-401. [CrossRef]

26. Schaltegger, S.; Synnestvedt, T.; Synnestvedt, T. The link between 'green' and economic success: Environmental management as the crucial trigger between environmental and economic performance. J. Environ. Manag. 2002, 65, 339-346.

27. Domańska, A.; Żukowska, B.; Zajkowski, R. Green entrepreneurship as a connector among social, environmental and economic pillars of sustainable development. Why some countries are more agile? Probl. Ekorozw. 2018, 13, 67-76.

28. Bae, T.J.; Qian, S.; Miao, C.; Fiet, J.O. The Relationship between Entrepreneurship Education and Entrepreneurial Intentions: A Meta-Analytic Review. Entrep. Theory Pract. 2014, 38, 217-254. [CrossRef]

29. Van Gelderen, M.; Kautonen, T.; Fink, M. From entrepreneurial intentions to actions: Self-control and action-related doubt, fear, and aversion. J. Bus. Ventur. 2015, 30, 655-673. [CrossRef]

30. Fayolle, A.; Liñán, F.; Moriano, J.A. Beyond entrepreneurial intentions: Values and motivations in entrepreneurship. Int. Entrep. Manag. J. 2014, 10, 679-689. [CrossRef] 
31. Krueger, N.F.; Carsrud, A.L. Entrepreneurial intentions: Applying the theory of planned behaviour. Entrep. Reg. Dev. 1993, 5, 315-330. [CrossRef]

32. Liñán, F.; Fayolle, A. A systematic literature review on entrepreneurial intentions: Citation, thematic analyses, and research agenda. Int. Entrep. Manag. J. 2015, 11, 907-933. [CrossRef]

33. Abosede, J.A.; Fayose, J.; Eze, B.U. Corporate Entrepreneurship and International Performance of Nigerian Banks. J. Econ. Manag. 2018, 32, 5-17. [CrossRef]

34. Ajzen, I. Perceived Behavioral Control, Self-Efficacy, Locus of Control, and the Theory of Planned Behavior. J. Appl. Soc. Psychol. 2002, 32, 665-683. [CrossRef]

35. Wilson, F.; Kickul, J.; Marlino, D. Gender, Entrepreneurial Self-Efficacy, and Entrepreneurial Career Intentions: Implications for Entrepreneurship Education. Entrep. Theory Pract. 2007, 31, 387-406. [CrossRef]

36. Bhaskar, A.U.; Garimella, S. A study of predictors of entrepreneurial intentions: Development of comprehensive measures. Glob. Bus. Rev. 2017, 18, 629-651. [CrossRef]

37. Bandura, A. Perceived self-efficacy in the exercise of control over AIDS infection. Eval. Program. Plan. 1990, 13, 9-17. [CrossRef]

38. Singh, S.K.; Del Giudice, M.; Chierici, R.; Graziano, D. Green innovation and environmental performance: The role of green transformational leadership and green human resource management. Technol. Forecast. Soc. Chang. 2020, 150, 119762. [CrossRef]

39. Ali, G.A.; Hilman, H.; Gorondutse, A.H. Effect of entrepreneurial orientation, market orientation and total quality management on performance: Evidence from Saudi SMEs. Benchmark. Int. J. 2020, 27, 1503-1531. [CrossRef]

40. Harrison, R.T.; Leitch, C.M. Entrepreneurship and leadership: The implications for education and development. Entrep. Reg. Dev. 1994, 6, 111-125. [CrossRef]

41. Dickson, V.V.; Buck, H.; Riegel, B. Multiple Comorbid Conditions Challenge Heart Failure Self-Care by Decreasing Self-Efficacy. Nurs. Res. 2013, 62, 2-9. [CrossRef]

42. Welpe, I.; Dowling, M. Venture-Capital-Finanzierung aus Sicht der Portfoliounternehmen. In Entrepreneurial Finance; Springer Science and Business Media LLC.: Berlin, Germany, 2005; pp. 277-299.

43. Lin, K.-Y.; Lu, H.-P. Why people use social networking sites: An empirical study integrating network externalities and motivation theory. Comput. Hum. Behav. 2011, 27, 1152-1161. [CrossRef]

44. Snyder, L.B.; Rouse, R.A. The Media Can Have More Than an Impersonal Impact: The Case of AIDS Risk Perceptions and Behavior. Health Commun. 1995, 7, 125-145. [CrossRef]

45. Gist, M.E.; Mitchell, T. Self-efficacy: A theoretical analysis of its determinants and malleability. Acad. Manag. Rev. 1992, 17, 183-211. [CrossRef]

46. Hajli, M.N. The role of social support on relationship quality and social commerce. Technol. Forecast. Soc. Chang. 2014, 87, 17-27. [CrossRef]

47. Adekiya, A.A.; Ibrahim, F. Entrepreneurship intention among students. The antecedent role of culture and entrepreneurship training and development. Int. J. Manag. Educ. 2016, 14, 116-132. [CrossRef]

48. Liñán, F. Skill and value perceptions: How do they affect entrepreneurial intentions? Int. Entrep. Manag. J. 2008, 4, 257-272. [CrossRef]

49. Solesvik, M.Z.; Westhead, P.; Matlay, H.; Parsyak, V.N. Entrepreneurial assets and mindsets: Benefit from university entrepreneurship education investment. Educ. Train. 2013, 55, 748-762. [CrossRef]

50. Abebe, M.A. Social and institutional predictors of entrepreneurial career intention: Evidence from hispanic adults in the U.S. J. Enterpris. Cult. 2012, 20, 1-23. [CrossRef]

51. Liñán, F.; Santos, F.J. Does Social Capital Affect Entrepreneurial Intentions? Int. Adv. Econ. Res. 2007, 13, 443-453. [CrossRef]

52. Nunnally, J.C. Psychometric Theory 3E; Tata McGraw-Hill Education: New York, NY, USA, 1994.

53. Krejcie, R.V.; Morgan, D.W. Determining Sample Size for Research Activities. Educ. Psychol. Meas. 1970, 30, 607-610. [CrossRef]

54. Kakish, I.; Al-Haddad, S. The impact of using social network sites on entrepreneurial project success. J. Fin. Mark. 2018, 74, 73-79.

55. Ramayah, T.; Rahman, S.A.; Taghizadeh, S.K. Modelling green entrepreneurial intention among university students using the entrepreneurial event and cultural values theory. Int. J. Entrep. Ventur. 2019, 11, 394-412. [CrossRef]

56. Tsai, K.-H.; Chang, H.-C.; Peng, C.-Y. Extending the link between entrepreneurial self-efficacy and intention: A moderated mediation model. Int. Entrep. Manag. J. 2016, 12, 445-463. [CrossRef]

57. Tan, K.L.; Suhaida, S.; Leong, Y.P. Self-Efficacy and green entrepreneurship. Proc. IOP Conf. Ser. Earth Environ. Sci. 2013, 16, 12119. [CrossRef]

58. Kave, L.; Podsakoff, P.M.; MacKenzie, S.B.; Lee, J.Y.; Podsakoff, N.P. Common method biases in behavioral research: A critical review of the literature and recommended remedies. J. Appl. Psychol. 2003, 88, 879-903.

59. Hair, J.F.; Celsi, M.; Ortinau, D.J.; Bush, R.P. Essentials of Marketing Research; McGraw-Hill/Irwin: New York, NY, USA, 2010; Volume 2.

60. Henseler, J.; Ringle, C.M.; Sarstedt, M. A new criterion for assessing discriminant validity in variance-based structural equation modeling. J. Acad. Mark. Sci. Vol. 2015, 43, 115-135. [CrossRef]

61. Fornell, C.; Larcker, D.F. Evaluating structural equation models with unobservable variables and measurement error. J. Mark. Res. 1981, 18, 39-50. [CrossRef]

62. Alayis, M.M.H.; Abdelwahed, N.A.A.; Atteya, N. Impact of Social Networking Sites' use on Entrepreneurial Intention Among Undergraduate Business Students: The Case of Saudi Arabia. Int. J. Entrep. 2018, 22, 1-18. 
63. García-Rodríguez, F.J.; Gil-Soto, E.; Ruiz-Rosa, I.; Sene, P.M. Entrepreneurial intentions in diverse development contexts: A cross-cultural comparison between Senegal and Spain. Int. Entrep. Manag. J. 2015, 11, 511-527. [CrossRef]

64. Hussain, I.; Nazir, M.; Hashmi, S.; Shaheen, I.; Akram, S.; Waseem, M.; Arshad, A. Linking Green and Sustainable Entrepreneurial Intentions and Social Networking Sites; The Mediating Role of Self-Efficacy and Risk Propensity. Sustainability 2021, $13,7050$. [CrossRef] 